\title{
Addition of Thiourea Host Monomer to Polymer Flocculants to Improve Selectivity of Phosphate Sorption
}

\author{
Timothy S. Goebel1,2, Kevin J. McInnes ${ }^{1}$, Scott A. Senseman ${ }^{3}$, Robert J. Lascano ${ }^{1}$, Alex M. Cullen ${ }^{4}$, \\ Timothy J. Fuhrer ${ }^{5}$, Sarah Pickle ${ }^{6}$, Netochi O. Adeolokun ${ }^{6}$, Todd A. Davis ${ }^{4}$
}

${ }^{1}$ USDA Wind, Erosion and Water Conservation Unit, Lubbock, TX, USA

${ }^{2}$ Department of Soil and Crop Sciences, Texas A \& M University, College Station, TX, USA

${ }^{3}$ Department of Plant Sciences, University of Tennessee, Knoxville, TN, USA

${ }^{4}$ Department of Chemistry, United States Air Force Academy, USAF Academy, Colorado Springs, CO, USA

${ }^{5}$ Department of Chemistry, Radford University, Radford, VA, USA

${ }^{6}$ Department of Chemistry, Idaho State University, Pocatello, ID, USA

Email: tim.goebel@usda.gov, k-mcinnes@tamu.edu, ssensema@utk.edu

How to cite this paper: Goebel, T.S., McInnes, K.J., Senseman, S.A., Lascano, R.J., Cullen, A.M., Fuhrer, T.J., Pickle, S., Adeolokun, N.O. and Davis, T.A. (2020) Addition of Thiourea Host Monomer to Polymer Flocculants to Improve Selectivity of Phosphate Sorption. Journal of Agricultural Chemistry and Environment, 9, 147-158. https://doi.org/10.4236/jacen.2020.93013

Received: May 13, 2020

Accepted: August 21, 2020

Published: August 24, 2020

Copyright $\odot 2020$ by author(s) and Scientific Research Publishing Inc. This work is licensed under the Creative Commons Attribution International License (CC BY 4.0).

http://creativecommons.org/licenses/by/4.0/

\begin{abstract}
Inorganic phosphate is a common nutrient that is applied as a fertilizer to both agricultural fields as well as urban settings such as private yards, public parks and other urban landscaping. While phosphate typically binds tightly to soil, movement of phosphate off of application sites can occur through soil erosion. The soil and its bound phosphate can then end up in surface waters such as rivers and lakes. Phosphate found in surface water bodies exists both as bound to the suspended clay as well as that free in solution. Elevated phosphate concentration in surface waters can lead to algal blooms and eutrophication. While the phosphate bound to clay in suspension in surface water bodies can be removed by commercially available polymer flocculants, the phosphate that is free in solution is more challenging as it is usually found in low concentrations and other anionic salts are generally present in higher concentrations. To remove phosphate from contaminated water systems, where other anions exist at higher concentrations, it is favorable to have a method of removal that is selective for phosphate. As a proof of principle, thiourea derivatized polymer flocculants were examined for the selective removal of phosphate in the presence of competing anions. The polymer flocculants exhibited selectivity for phosphate through hydrogen bonding and were effective at removing up to $43 \%$ of phosphate from simulated wastewater. Computational studies and ${ }^{1} \mathrm{H}$ NMR were used to investigate the selectivity of the thiourea monomer for phosphate over competing anions such as chloride and sulfate.
\end{abstract}




\section{Keywords}

Molecular Recognition, Thiourea, Polymers, Flocculants, Phosphate

\section{Introduction}

Phosphate is an essential plant nutrient that is applied as a fertilizer to agricultural crops and to urban landscapes. While phosphate applied to a field benefits the crops being produced, it may also move off site into rivers and lakes [1] [2]. In rivers and lakes, phosphate is generally a limiting nutrient for the microorganisms present. The influx of phosphate can cause proliferation of cyanobacteria resulting in potential human health hazards as well as the aforementioned damage to the ecosystem via eutrophication [1].

Phosphate that is applied to fields is generally bound tightly to the soil and will have little movement through the soil profile [3]. Phosphate generally moves through the environment only when the soil it is bound to begins to move, usually through erosion processes. Once the soil moves into a surface water body it can become suspended and the phosphate will come to an equilibrium between the soil bound and aqueous portions based on environmental conditions such as $\mathrm{pH}$ and temperature of the water present [3]. Currently, polymer flocculants as well as other coagulants are effective at removing the suspended solids and the phosphate bound to them; however, they remove little if any of the phosphate that is free in aqueous solution [4] [5].

While phosphate is generally a limiting nutrient, it is not the only anion present in surface water systems. Other anions such as chloride $\left(\mathrm{Cl}^{-}\right)$and hydrogen sulfate $\left(\mathrm{HSO}_{4}^{-}\right)$are also present and are generally at higher concentrations than phosphate [6]. To remove phosphate from water systems, the method would be most efficient if it were selective for phosphate in the presence of other anions. Many methods have been investigated to remove excess phosphate from water such as chitosan-based flocculants, as well as, agricultural and industrial waste products such as mango seeds and even concrete [7] [8] [9]. Recently, molecularly imprinted polymers containing thiourea were shown to selectively remove phosphate from river water with up to $60 \%$ efficiency [10].

Based on previous studies, thiourea derivatized trapping groups are attractive, and have been shown to exhibit strong binding affinities to anions, specifically phosphate. The ability of thiourea to form strong hydrogen bonding interactions with oxyanions leads to high binding energies in solution. Based on these strong interactions, our laboratories have investigated the use of thiourea-derivatized polymer flocculants to remove both soluble and colloidally sorbed phosphate from suspension [4]. This polymer flocculant was designed with a strategically placed $3^{\text {rd }}$ site for hydrogen to favor and promote the binding of phosphate in the presence of other anions such as chloride and $\mathrm{HSO}_{4}^{-}$. To expand on our previous studies, we devised a series of experiments as a proof of concept. Our ob- 
jective was to test phosphate binding to thiourea-derivatized polymers immersed in simulated wastewater with high concentrations of competitive anions as well as, computational and ${ }^{1} \mathrm{H}$ NMR studies. The purpose of these experiments was to support selectivity of our newly developed thiourea trapping group.

\section{Materials and Methods}

\subsection{General Methods}

All reactions were performed in oven-dried glassware under an inert atmosphere of nitrogen. Solvents were dried by passing through a solvent dry system (MBRAUN MB-SPS). All chemicals were purchased from VWR and were used without further purification. ${ }^{1} \mathrm{H}$ NMR and ${ }^{13} \mathrm{C}$ NMR spectra were recorded on a 300 or $500 \mathrm{MHz}$ (JEOL JNM-ECX-300/500) multinuclear spectrometer. ${ }^{1} \mathrm{H}$ NMR and ${ }^{13} \mathrm{C}$ NMR spectra were referenced to $\mathrm{TMS}, \mathrm{CD}_{3} \mathrm{CN}$ or DMSO. Fourier Transform Infrared spectroscopy (FT-IR) was performed on a Perkin Elmer Spectrum RX I using a thin film KBr pellet. Gas chromatography-TCD was performed on a Shimadzu GC-2010 with a Restek (RTX ${ }^{\oplus}-5 \mathrm{MS}, 15 \mathrm{~m} \times 0.25 \mathrm{~mm}$ ID $\times 0.25 \mu \mathrm{m})$ column. Gas chromatography-mass spectrometry data was obtained from a Shimadzu GCMS-QP2010S equipped with a Restek (RTX ${ }^{\bullet}$-5MS, $15 \mathrm{~m} \times$ $0.25 \mathrm{~mm} \mathrm{ID} \times 0.25 \mu \mathrm{m})$ column. GC and GC-MS conditions were as follows: initial temp $60^{\circ} \mathrm{C}$ hold 3 minutes, ramp $15^{\circ} \mathrm{C} / \mathrm{min}$, final temperature $300^{\circ} \mathrm{C}$ hold 3 minutes. Reported melting points were conducted using a Mel-Temp apparatus and are uncorrected. Ion Chromatography (Conducted at Texas A \& M Nutrient and Water Analysis Research Laboratory). Ion chromatography samples were run using a DIONEX ICS 2000 Ion Chromatography system equipped with AS20 and AG20 columns eluting with $35 \mathrm{mM} \mathrm{KOH}$ at a flow of rate $1 \mathrm{~mL} / \mathrm{min}$ with $25 \mu \mathrm{L}$ injection volumes.

\subsection{Preparation of $N$-(Aminophenylcarbamothioyl)acrylamide}

Ammonium thiocyanate $(0.500 \mathrm{~g}, 6.56 \mathrm{mmol})$ was dissolved in dry acetone (25 $\mathrm{mL}$ ) and added to a flame dried round bottom flask under N2. The reaction was cooled to $0^{\circ} \mathrm{C}$ and acroyl chloride $(0.550 \mathrm{~mL}, 7.22 \mathrm{mmol})$ was added slowly over 15 minutes. The reaction was allowed to stir at $0^{\circ} \mathrm{C}$ for 30 minutes during which time a white suspension formed. After 30 minutes the suspension was vacuum filtered and the solution returned to a clean dry round bottom and cooled to $0^{\circ} \mathrm{C}$. $o$-Phenylenediamine $(0.708 \mathrm{~g}, 32.8 \mathrm{mmol})$ dissolved in dry acetone $(3 \mathrm{~mL})$ was added via syringe over 30 minutes and the reaction was allowed to stir for an additional 30 minutes at $0^{\circ} \mathrm{C}$ under $\mathrm{N}_{2}$. The reaction was then added over 15 minutes to an ice/water bath $(150 \mathrm{~mL})$ and yellow crystals began to form. The resulting crystals were vacuum filtered to yield a yellow solid as the final product. Yellow solid (Yield 75\%) $\mathrm{mp}=134.2^{\circ} \mathrm{C}-136.0^{\circ} \mathrm{C} .{ }^{1} \mathrm{H} \mathrm{NMR}(300 \mathrm{MHz}$, DMSO): $\delta: 5.02(\mathrm{~s}, 2 \mathrm{H}), 5.96(\mathrm{dd}, J z=9.6 \mathrm{~Hz}, 1.8 \mathrm{~Hz}), 6.40(\mathrm{dd}, J z=17.0 \mathrm{~Hz}, 1.8$ $\mathrm{Hz}), 6.51-6.65(\mathrm{~m}, 2 \mathrm{H}), 6.72(\mathrm{dd}, J z=8.0 \mathrm{~Hz}, 1.4 \mathrm{~Hz}), 6.96(\mathrm{~m}, 1 \mathrm{H}), 7.25(\mathrm{dd}, J z$ $=7.8 \mathrm{~Hz}, 1.4 \mathrm{~Hz}), 11.53(\mathrm{~s}, 1 \mathrm{H}), 11.87(\mathrm{~s}, 1 \mathrm{H}) .{ }^{13} \mathrm{C}$ NMR (75 MHz, DMSO): $\delta$ : 


\subsection{Preparation of Thiourea Based Polymer}

To a stirring solution of $40 \mathrm{ml}$ acetonitrile was added: $4.00 \mathrm{~g}$ (0.0206 mol) of (1), $2.98 \mathrm{~g}(0.0412 \mathrm{~mol})$ acrylamide, and $8.458 \mathrm{~g}(0.0412 \mathrm{~mol})$ acryloxyethyltrimethylammonium chloride. The solution was then sparged with nitrogen for $1 \mathrm{~h}$, while the temperature was raised from room temperature to $30^{\circ} \mathrm{C}$. To a stirring solution, $0.169 \mathrm{~g}\left(1.03 \times 10^{-3} \mathrm{~mol}\right)$ azobisisobutyronitrile (AIBN) was added to initiate polymerization. The reaction temperature peaked at $38^{\circ} \mathrm{C}$. The reaction was then heated to $50^{\circ} \mathrm{C}$ and allowed to react for $16 \mathrm{~h}$. The reaction produced a slightly yellow solid that was ground in a mortar and pestle to a $1.2-\mathrm{mm}$ diameter powder and analyzed by IR TGA/DSC. Other polymers with different densities and a different thiourea molecule were made using the same methods changing the mole percentage of monomers.

\subsection{Phosphate Sequestration Experiment}

A suspension of water and clay was made by adding $250 \mathrm{mg}$ kaolinite to $19 \mathrm{ml}$ of DI water and the clay was allowed to hydrate overnight. To this suspension $0.5 \mathrm{ml}$ of a phosphate intermediate standard was added to the suspension to give a final concentration of $5 \mathrm{mg} / \mathrm{L}$. To the phosphate suspension was added $0.5 \mathrm{ml}$ of a polymer intermediate solution to give a final polymer concentration of $100 \mathrm{mg} / \mathrm{L}$. The final mixture was vortexed for 5 seconds and then shaken for 12 hours. The mixture was allowed to settle and a $5 \mathrm{ml}$ aliquot was taken and centrifuged on a Fischer Scientific Model 225 centrifuge at $305 \mathrm{~g}$ for 10 minutes. A $2 \mathrm{ml}$ subsample was then taken and filtered through a 0.4 -micron syringe filter prior to analysis by ion chromatography.

\subsection{Computational Methods}

All models for this work were computed using the Gaussian 09 suite of programs, including use of Gaussview 5 to generate three-dimensional figures [12]. Each molecule was modeled separately beginning with geometries optimized first using molecular mechanics and then using the PM3 semi-empirical method to generate starting structures for density functional theory. Each structure was then optimized using the M06-2X/6-311G (d) model chemistry. Geometries optimized with DFT were checked with frequency analysis at the same level of theory as the optimization.

\section{Results and Discussion}

\subsection{Polymer Sorption Study}

In this proof of concept study, the goal was to test the affinity of the polymer for phosphate in suspensions containing anions at concentrations typical of wastewater [7]. Suspensions of clay (kaolinite) were developed using $250 \mathrm{mg}$ clay in $18.5 \mathrm{ml}$ of water and allowed to hydrate overnight. To the clay suspension, 0.5 
$\mathrm{ml}$ of an intermediate solution was added to give final anion concentrations of: $190 \mathrm{mg} / \mathrm{L}\left(\mathrm{NH}_{4}\right)_{2} \mathrm{SO}_{4}, 28 \mathrm{mg} / \mathrm{L} \mathrm{CaCl} 2,180 \mathrm{mg} / \mathrm{L} \mathrm{MgSO}$, and $5 \mathrm{mg} / \mathrm{L} \mathrm{NaH}_{2} \mathrm{PO}_{4}$. The suspension was vortexed, and $1 \mathrm{ml}$ of an intermediate polymer solution was added to give a final polymer dose of $100 \mathrm{mg} / \mathrm{L}$. The resulting suspension was vortexed and placed on a shaker for 12-h. The tubes were removed from the shaker and a $5 \mathrm{ml}$ aliquot of the water above the floc layer was taken, centrifuged and filtered prior to analysis by ion chromatography. The polymers tested were: Magnifloc $494 \mathrm{C}^{\circ}$ a cationic polymer with $10 \%$ positive charge density (A), a control polymer $\mathrm{C} 40-00$ a cationic polymer with $40 \%$ positive charge density (B), and an experimental polymer C40-20 containing $40 \%$ positive charge density and $20 \%$ of the 3-point thiourea monomer (C), shown in Table 1 [5].

The results from the control experiments were as follows: the clay adsorbed more than $30 \%$ of the phosphate from solution regardless of the presence of competitive anions (Figure 1(a)). This result was due to the interaction of phosphate with the exposed aluminum octahedral layer found on kaolinite [11]. The addition of Magnifloc $494 \mathrm{C}^{\circ}$, did not remove more phosphate from the suspension. In fact, addition of Magnifloc 494C appeared to decrease the amount of phosphate adsorbed to the clay, likely competing for adsorption sites on the exposed alumina layer (Figure $1(\mathrm{~b})$ ). The control polymer C40-00, containing the trimethyl ammonium monomer at $40 \%$, removed an additional $20 \%$ of the phosphate from suspension without competing anions, likely from an interaction between the negatively charged phosphate and the positively charged quaternary ammonium ion present (Figure 1(b)). When competing anions were introduced into the suspension, C40-00 was not as effective at removing phosphate. The lack of selectivity of the quaternary ammonium ion resulted in an overall amount of phosphate removed similar to that of Magnifloc 494C. While the higher charge density on C40-00 results in more positively charged groups available to interact with phosphate in bulk solution, the available quaternary ammonium ion was not selective for phosphate.

The experimental polymer C40-20, offering three-point binding with phosphate, removed $24 \%$ more phosphate than the control containing only clay without competing anions, and $13 \%$ in the presence of other anions (Figure 1(b)). The C40-20 polymer had two groups that could interact with phosphate:

Table 1. Mole percent of monomers for polymers tested.

\begin{tabular}{cccc}
\hline Magnifloc $494 \mathrm{C}^{\circ}$ & $\begin{array}{c}\mathrm{C} 40-00 \\
\text { (A) }\end{array}$ & $\begin{array}{c}\mathrm{C} 40-20 \\
\text { (B) }\end{array}$ \\
\hline & 90 & 60 & 40 \\
& 10 & 40 & 40 \\
\hline
\end{tabular}




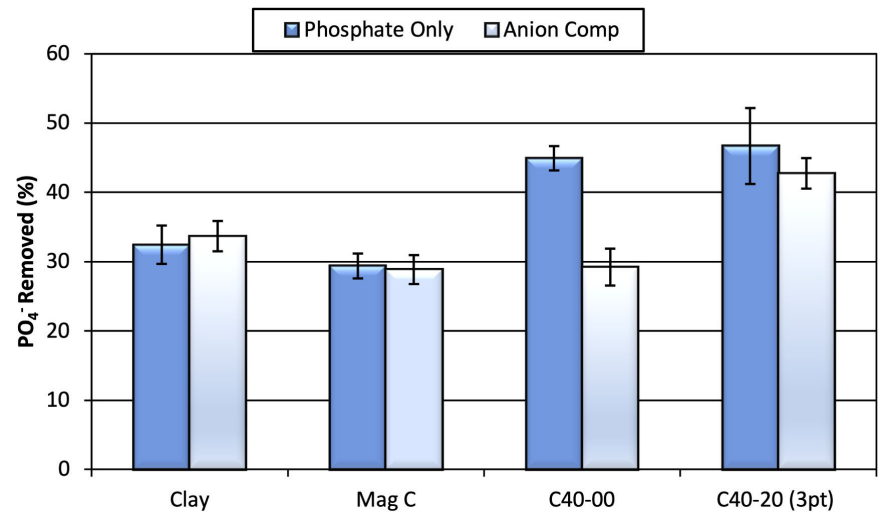

(a)

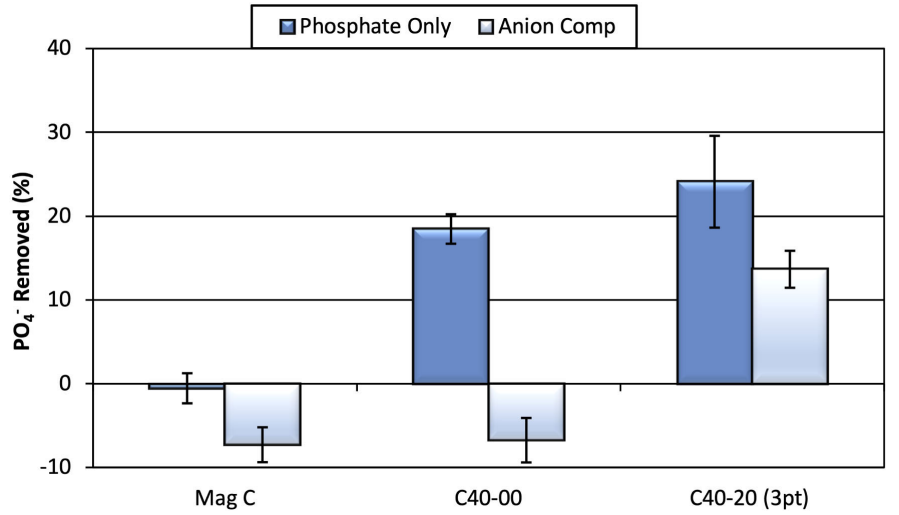

(b)

Figure 1. Phosphate removed by polymers from a clay suspension having an initial concentration of $5 \mathrm{mg} / \mathrm{L} \mathrm{H}_{2} \mathrm{PO}_{4}^{-}$. (a) $\mathrm{H}_{2} \mathrm{PO}_{4}^{-}$removed in the presence of other anions at concentrations similar to wastewater and (b) the same results with the phosphate removed by the clay partitioned to examine the portion removed by the polymers.

the thiourea and the positively charged quaternary ammonium ion. The decrease in phosphate removal by the polymer when other anions were present was likely due to the interaction of anions with the quaternary ammonium group on the polymer. The control polymers showed the quaternary ammonium ion was unable to maintain phosphate sorption in the presence of competitive anions. These results indicated that the remaining $13 \%$ of phosphate removed in the presence of competing anions was due to the interaction of the thiourea with phosphate. This further indicated that the thiourea group may be selective for phosphate in the presence of other anions. To further investigate the selectivity of the thiourea for phosphate in the presence of competing anions, ${ }^{1} \mathrm{H}$ NMR and UV-V is experiments were conducted to examine the affinity of thiourea for phosphate in the presence of chloride and sulfate.

\subsection{Computational and ${ }^{1} \mathrm{H}$ NMR Anion Binding Studies}

Density functional theory (DFT) computational studies were conducted in acetonitrile and water to determine the binding energies between the three-point hydrogen bonding thiourea trapping group and anions $\left(\mathrm{Cl}^{-}, \mathrm{HSO}_{4}^{-}\right.$, and $\left.\mathrm{H}_{2} \mathrm{PO}_{4}^{-}\right)$ 
[12] [13] [14] [15]. Each molecule was calculated for a base line energy and then the computations were conducted with binding of the anions in both acetonitrile and water (Table 2). The results exhibit the same trend observed with the flocculation studies. The strength of binding increases from chloride $>$ hydrogen sulfate > dihydrogen phosphate in both acetonitrile and $\mathrm{H}_{2} \mathrm{O}$. Using acetonitrile as the solvent, the binding of phosphate is approximately $5 \mathrm{kcal} / \mathrm{mol}$ greater in comparison to sulfate and $9 \mathrm{kcal} / \mathrm{mol}$ for chloride respectively.

When the solvent is changed to water, the binding energy difference between phosphate and sulfate are again approximately the same as acetonitrile, however, chloride decreased by approximately $4 \mathrm{kcal} / \mathrm{mol}$. The lower binding affinity for chloride can be attributed to the stronger solvation effects of $\mathrm{Cl}^{-}$in $\mathrm{H}_{2} \mathrm{O}$ compared to acetonitrile.

To further test anion binding affinity, ${ }^{1} \mathrm{H}$ NMR titration experiments were conducted with $\mathrm{Cl}^{-}$(tetrabutylammonium chloride/TBACl), $\mathrm{HSO}_{4}^{-}$(tetrabutylammonium hydrogen sulfate/TBAS), and tetrabutylammonium dihydrogen phosphate/TBAP) [16]-[27]. To examine these interactions by ${ }^{1} \mathrm{H} \mathrm{NMR}$, the thiourea samples were prepared at a 4 millimolar concentration and the anions were titrated up to 6.00 equivalents $(24.0 \mathrm{mM})$ in $\mathrm{CD}_{3} \mathrm{CN}$ and $\mathrm{DMSO}_{\mathrm{d} 6}$. A stronger hydrogen bonding interaction was observed between the monomer and phosphate, in comparison to $\mathrm{Cl}^{-}$and $\mathrm{HSO}_{4}^{-}$(Figure 2). Increasing the concentration (0.0 - 6.0 equiv.) of $\mathrm{Cl}^{-}$, leads to a downfield shift in both $\mathrm{H}_{\mathrm{a}}$ and the aromatic region. $\mathrm{H}_{\mathrm{a}}$ shifts from $9.40 \mathrm{ppm}$ to $9.90 \mathrm{ppm}$ upon the addition of 3.00 - 6.00 equivalents displaying the interaction of the chlorine with one of the thiourea protons. For the titration using TBAS little change is observed using Hydrogen Sulfate. Upon titration with dihydrogen phosphate a significant shift in both the thiourea $\mathrm{H}_{\mathrm{a}}$ and $\mathrm{H}_{\mathrm{b}}$ protons is observed. An upfield shift of $\mathrm{Hb}$ from

Table 2. Calculated binding energies for anions with thiourea host in acetonitrile and water. Relative energies obtained from DFT calculations were performed on each of the molecules and then with hydrogen binding. These energies were then subtracted to obtain the calculated values (M06-2X/6-311G (d)).

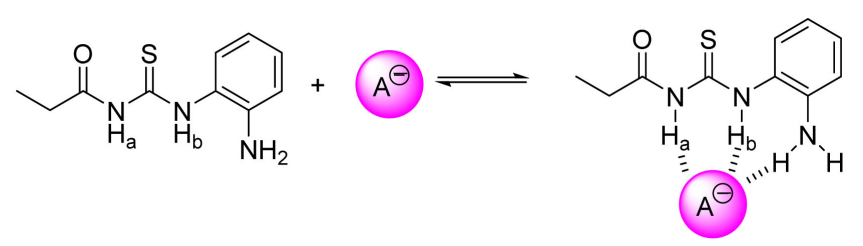

\begin{tabular}{ccc}
\hline Anion & Solvent & Binding Energy (Kcal/mol) \\
\hline Chloride $\left(\mathrm{Cl}^{-}\right)$ & Acetonitrile & -6.76 \\
Hydrogen Sulfate $\left(\mathrm{HSO}_{4}^{-}\right)$ & Acetonitrile & -10.15 \\
Dihydrogen Phosphate & Acetonitrile & -15.30 \\
Chloride $\left(\mathrm{Cl}^{-}\right)$ & $\mathrm{H}_{2} \mathrm{O}$ & -2.65 \\
Hydrogen Sulfate $\left(\mathrm{HSO}_{4}^{-}\right)$ & $\mathrm{H}_{2} \mathrm{O}$ & -10.42 \\
Dihydrogen Phosphate $\left(\mathrm{H}_{2} \mathrm{PO}_{4}^{-}\right)$ & $\mathrm{H}_{2} \mathrm{O}$ & -15.02 \\
\hline
\end{tabular}




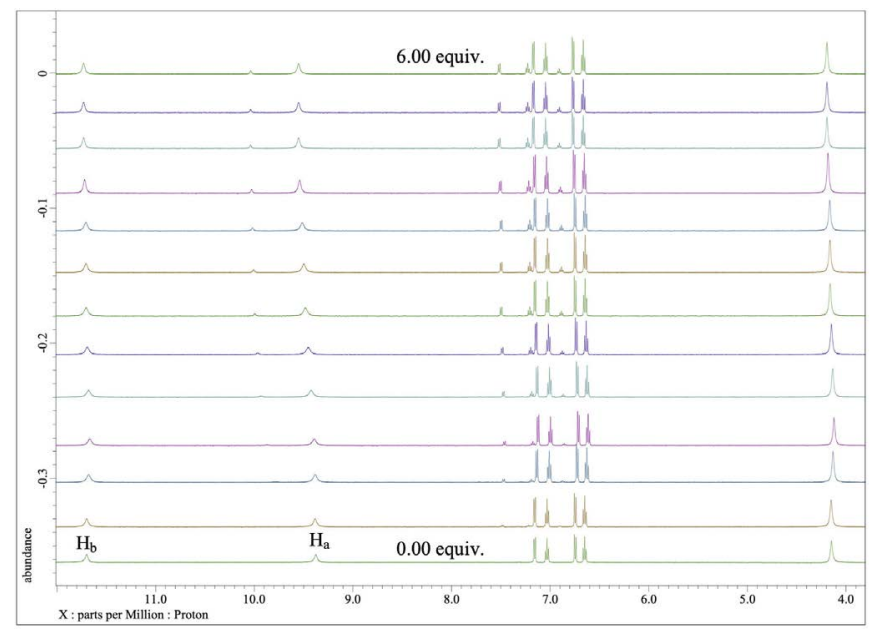

(a)

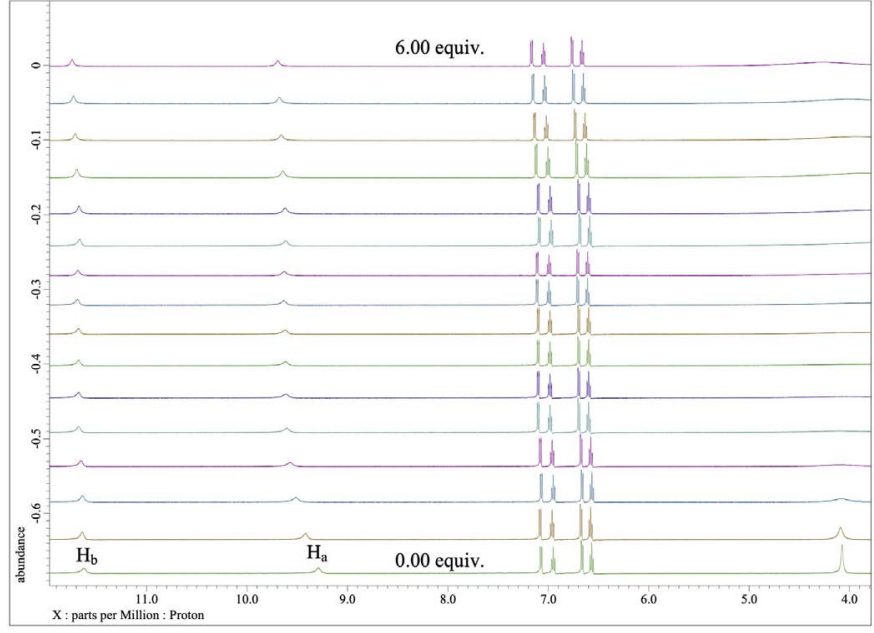

(b)

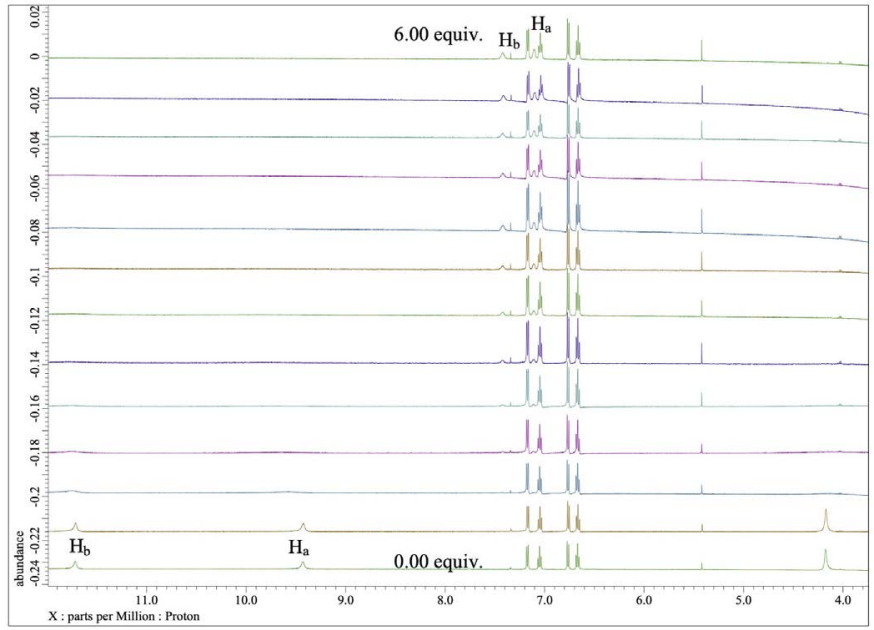

(c)

Figure 2. ${ }^{1} \mathrm{H}$ NMR of: (a) Three-point thiourea and tetrabutyl ammonium chloride $\left(\mathrm{Cl}^{-}\right)$ (6.00 equiv.), Titration with $\mathrm{Cl}^{-}$; (b) Tetrabutylammoniumhydrogensulfate $\left(\mathrm{HSO}_{4}^{-}\right)(6.00$ equiv.), Titration with $\mathrm{HSO}_{4}^{-}$; and (c) Tetrabutyl ammonium dihydrogen phosphate $\mathrm{H}_{2} \mathrm{PO}_{4}^{-}$(6.00 equiv.) in $\mathrm{CD} 3 \mathrm{CN}$, Titration with $\mathrm{H}_{2} \mathrm{PO}_{4}^{-}$. 
$11.80 \mathrm{ppm}$ to $7.40 \mathrm{ppm}$ and $\mathrm{H}_{\mathrm{a}}$ from $9.40 \mathrm{ppm}$ to $7.50 \mathrm{ppm}$ was observed. The large shift of the thiourea protons indicates stronger hydrogen bonding interaction in comparison to $\mathrm{Cl}^{-}$and $\mathrm{HSO}_{4}^{-}$supporting both the flocculation and computational studies.

The acid/base reaction of inorganic phosphate with thiourea in DMSO has been prevalent in the chemical literature [28]. To ensure that a hydrogen bonding interaction is occurring and not acid/base chemistry, tetrabutylammonium hydroxide was added to a thiourea host in $\mathrm{DMSO}_{\mathrm{d} 6}$. A significant change was observed in the removal of the thiourea proton the aromatic region of the ${ }^{1} \mathrm{H}$ NMR. Due to the absence of these changes in the anion titrations, it is evident that the interaction of inorganic phosphate occurs via hydrogen and not Bronsted-Lowry acid/base chemistry. Both the computational studies and the titration support the polymer flocculent results in that dihydrogen phosphate has a higher affinity for the thiourea trapping group in comparison to the hydrogen sulfate and chloride.

\section{Conclusion}

The study described herein show that the addition of thiourea to a polymer flocculent results in a material that can be used to remove both the sorbed and soluble phosphate from wastewater. In contrast to our thiourea derivatized polymer flocculants, the control polymers tested had no selectivity for phosphate in the presence of competing anions. From the computational and ${ }^{1} \mathrm{H}$ NMR titration studies, it appeared that the thiourea monomer had a higher affinity for $\mathrm{H}_{2} \mathrm{PO}_{4}^{-}$than $\mathrm{Cl}^{-}$or $\mathrm{HSO}_{4}^{-}$, supporting our observation of selectivity in the polymer flocculent studies. It is believed that the higher affinity of the monomer for phosphate is due to the ability of a third hydrogen bonding interaction that is not existent with sulfate or chloride. This interaction would make this an enthalpically driven process where the ability to form the third hydrogen bond provided the anion selectivity. Currently, an investigation into the interaction of phosphate with the monomer using calorimetry is underway to determine the thermodynamics of this interaction.

\section{Acknowledgements}

T.A.D. would like to acknowledge funding from Air Force Office of Sponsored Programs and U.S. Air Force Academy Department of Chemistry. We would like to thank Dr.'s Gemma Aragay and Pablo Ballester for insightful discussions.

Mention of trade names or commercial products in this publication is solely for the purpose of providing specific information and does not imply recommendation or endorsement by the U.S. Department of Agriculture.

USDA is an equal opportunity provider and employer.

\section{Conflicts of Interest}

The authors declare no conflicts of interest regarding the publication of this paper. 


\section{References}

[1] Pote, D.H., Daniel, T.C., Moore, P.A., Nichols, D.J., Sharpley, A.N. and Edwards, D.R. (1996) Relating Extractable Soil Phosphorus to Phosphorus Losses in Runoff. Soil Science Society America Journal, 60, 855-859. https://doi.org/10.2136/sssaj1996.03615995006000030025x

[2] Maguire, R.O., Sims, J.T. and Coale, F.J. (2000) Phosphorus Fractionation in Biosolids-Amended Soils Relationship to Soluble and Desorbable Phosphorus. Soil Science Society America Journal, 64, 2018-2024. https://doi.org/10.2136/sssaj2000.6462018x

[3] McBride, M.R. (1994) Environmental Chemistry of Soils. Oxford University Press, New York.

[4] Goebel, T., Lascano, R. and Davis, T. (2016) Phosphate Sorption in Water by Several Cationic Polymer Flocculants. Journal of Agricultural Chemistry and Environment, 5, 45-51. https://doi.org/10.4236/jacen.2016.51005

[5] Goebel, T.S., McInnes, K.J., Senseman, S.A., Lascano, R.J., Marchand, L.S. and Davis, T.A. (2011) Modifying Polymer Flocculants for the Removal of Inorganic Phosphate from Water. Tetrahedron Letters, 52, 5241-5244. https://doi.org/10.1016/j.tetlet.2011.07.130

[6] Livingstone, D.A. (1963) Chemical Composition of Rivers and Lakes. US Geological Survey Professional Paper No. 440, 1-2. https://doi.org/10.3133/pp440G

[7] Yang, R., Li, H., Huang, M., Yang, H. and Li, A. (2016) A Review on Chitosan-Based Flocculants and Their Applications in Water Treatment. Water Resources, 95, 59-89. https://doi.org/10.1016/j.watres.2016.02.068

[8] Patel, J.B. and Sudhakar, P. (2001) Phosphate Removal from Aqueous Solutions Using Mango Seed Powder. Journal of Industrial Pollution Control, 17, 213-218. http://nopr.niscair.res.in/handle/123456789/18924

[9] Oğuz, E., Gürses, A. and Canpolat, N. (2003) Removal of Phosphate from Wastewaters. Cement and Concrete Research, 33, 1109-1112. https://doi.org/10.1016/S0008-8846(03)00016-4

[10] Kugimiya, A. and Takei, H. (2008) Selective Recovery of Phosphate from River Water Using Molecularly Imprinted Polymers. Analytical Letters, 41, 302-311. https://doi.org/10.1080/00032710701792919

[11] Muljadi, D., Posner, A.M. and Quirk, J.P. (1966) The Mechanism of Phosphate Adsorption by Kaolinite, Gibbsite, and Pseudoboehmite: Part I. The Isotherms and the Effect of pH on Adsorption. Journal of Soil Science, 17, 212-228. https://doi.org/10.1111/j.1365-2389.1966.tb01467.x

[12] Frisch, M.J., Trucks, G.W., Schlegel, H.B., Scuseria, G.E., Robb, M.A.,Cheeseman, J.R., Scalmani, G., Barone, V., Mennucci, B., Petersson, G.A., Nakatsuji, H., Caricato, M., Li, X., Hratchian, H.P., Izmaylov, A.F., Bloino, J., Zheng, G., Sonnenberg, J.L., Hada, M., Ehara, M., Toyota, K., Fukuda, R., Hasegawa, J., Ishida, M., Nakajima, T., Honda, Y., Kitao, O., Nakai, H., Vreven, T., Montgomery, J.A., Peralta, J.E., Ogliaro, F., Bearpark, M., Heyd, J.J., Brothers, E., Kudin, K.N., Staroverov, V.N., Kobayashi, R., Normand, J., Raghavachari, K., Rendell, A., Burant, J.C., Iyengar, S.S., Tomasi, J., Cossi, M., Rega, N., Millam, J.M., Klene, M., Knox, J.E., Cross, J.B., Bakken, V., Adamo, C., Jaramillo, J., Gomperts, R., Stratmann, R.E., Yazyev, O., Austin, A.J., Cammi, R., Pomelli, C., Ochterski, J.W., Martin, R.L., Morokuma, K., Zakrzewski, V.G., Voth, G.A., Salvador, P., Dannenberg, J.J., Dapprich, S., Daniels, A.D., Farkas, Foresman, J.B., Ortiz, J.V., Cioslowski, J. and Fox, D.J. (2009) Gaussian 09, Revision B.01. Wallingford. 
Ii, R., Keith, T., Millam, J., Eppinnett, K., Hovell, L. and Gilliland, R. (2009) GaussView, Version 5.

[13] Miertuš, S., Scrocco, E. and Tomasi, J. (1981) Electrostatic Interaction of a Solute with a Continuum. A Direct Utilization of $a b$ Initio Molecular Potentials for the Prevision of Solvent Effects. Chemical Physics, 55, 117-129. https://doi.org/10.1016/0301-0104(81)85090-2

[14] Miertuš, S. and Tomasi, J. (1982) Approximate Evaluations of the Electrostatic Free Energy and Internal Energy Changes in Solution Processes. Chemical Physics, 65, 239-245. https://doi.org/10.1016/0301-0104(82)85072-6

[15] Pascual-ahir, J.L., Silla, E. and Tuñon, E. (1994) GEPOL: An Improved Description of Molecular Surfaces. III. A New Algorithm for the Computation of a Solvent-Excluding Surface. Journal of Computational Chemistry, 15, 1127-1138. https://doi.org/10.1002/jcc.540151009

[16] Hay, B.J. (2010) De Novo Structure-Based Design of Anion Receptors. Chemical Society Reviews, 39, 3700-3708. https://doi.org/10.1039/c0cs00075b

[17] Dos Santos, C.M.G., McCabe, T., Watson, G.W., Kruger, P.E. and Gunnlaugsson, T. (2008) The Recognition and Sensing of Anions Through "Positive Allosteric Effects" Using Simple Urea-Amide Receptors. Journal of Organic Chemistry, 73, 9235-9244. https://doi.org/10.1021/jo8014424

[18] Linton, B. and Hamilton, A.D. (1999) Calorimetric Investigation of GuanidiniumCarboxylate Interactions. Tetrahedron, 55, 6027-6038.

https://doi.org/10.1016/S0040-4020(99)00277-X

[19] Kelly, T.R. and Kim, M.H. (1994) Relative Binding Affinity of Carboxylate and Its Isosteres: Nitro, Phosphate, Phosphonate, Sulfonate, and $\delta$-Lactone. Journal of the American Chemical Society, 116, 7072-7080. https://doi.org/10.1021/ja00095a009

[20] Hay, B.J., Firman, T.K. and Moyer, B.A. (2005) Structural Design Criteria for Anion Hosts: Strategies for Achieving Anion Shape Recognition through the Complementary Placement of Urea Donor Groups. Journal of the American Chemical Society, 127, 1810-1819. https://doi.org/10.1021/ja043995k

[21] Gunnlaugsson, T., Kruger, P.E., Jensen, P., Tierney, J., Ali, H.D.P. and Hussey, G.M. (2004) Colorimetric "Naked Eye" Sensing of Anions in Aqueous Solution. Journal of Organic Chemistry, 70, 10875-10878. https://doi.org/10.1021/jo0520487

[22] Jose, D.A., Kumar, D.K., Ganguly, B. and Das, A. (2004) Efficient and Simple Colorimetric Fluoride Ion Sensor Based on Receptors Having Urea and Thiourea Binding Sites. Organic Letters, 6, 3445-3448. https://doi.org/10.1021/ol048829w

[23] Cho, E.J., Ryu, B.J., Lee, Y.J. and Nam, K.C. (2005) Visible Colorimetric Fluoride Ion Sensors. Organic Letters, 7, 2607-2609. https://doi.org/10.1021/ol0507470

[24] Pfeffer, F.M., Gunnlaugsson, T., Jensen, P. and Kruger, P.E. (2005) Anion Recognition Using Preorganized Thiourea Functionalized [3]Polynorbornane Receptors. Organic Letters, 7, 5357-5360. https://doi.org/10.1021/ol051497q

[25] Perez-Casas, C. and Yatsimirsky, A.K. (2008) Detailing Hydrogen Bonding and Deprotonation Equilibria between Anions and Urea/Thiourea Derivatives. Journal of Organic Chemistry, 73, 2275-2284. https://doi.org/10.1021/jo702458f

[26] Marti-Centelles, V., Burguete, M.I., Galindo, F., Izquierdo, M.A., Kumar, K., White, A.J.P., Luis, S.V. and Vilar, R. (2012) Fluorescent Acridine-Based Receptors for $\mathrm{H}_{2} \mathrm{PO}_{4}^{-}$. Journal of Organic Chemistry, 77, 490-500. https://doi.org/10.1021/jo202077v

[27] Bregovic, N., Cindro, N., Frkanec, L., Uzarevic, K. and Tomisic, V. (2014) Thermo- 
dynamic Study of Dihydrogen Phosphate Dimerisation and Complexation with Novel Urea- and Thiourea-Based Receptors. Chemistry: A European Journal, 20, 15863-15871. https://doi.org/10.1002/chem.201404091

[28] Bonizzoni, M., Fabbrizzi, L., Taglietti, A. and Tiengo, F. (2006) (Benzylideneamino) Thioureas-Chromogenic Interactions with Anions and N-H Deprotonation. European Journal of Organic Chemistry, 2006, 3567-3574.

https://doi.org/10.1002/ejoc.200600388 